\title{
Influence of geomagnetism and salinity on the directional choice of eels
}

\author{
F.-W. TESCH \\ Biologische Anstalt Helgoland (Zentrale); \\ Hamburg 50, Federal Republic of Germany
}

\begin{abstract}
KURZFASSUNG: Einfluß von Erdmagnetismus und Salzgehalt auf die Richtungswahl von Aalen. 25 Blankaale von Anguilla anguilla und A. rostrata wurden in Süß- und Meerwasser sowie unter veränderten Bedingungen des erdmagnetischen Feldes hinsichtlich ihrer Richtungseinstellung untersucht. Hierzu dienten ein Rundbecken, ein Helmholtz-Spulen-Paar sowie eine photographische Registriereinrichtung. Die Aale bewegten sich in der Versuchsanlage wenig. Sie bevorzugten im Seewasser und unter natürlichen Magnetfeldbedingungen, ähnlich wie bei früheren Untersuchungen, eine nördliche oder südliche Richtungseinstellung. Kompensierung der Nordkomponente $\left(0^{\circ}\right)$ des Erdfeldes rief im Meerwasser bei Aalen aller drei Herkunftsorts (Elbe, Hamburg und Brunsbüttel, Küste von Rhode Island, USA) eine Bevorzugung östlicher Richtungen hervor. Umkehrung der magnetischen Nordkomponente auf geographisch Süd verursachte keine Veränderung gegenüber dem Verhalten im natürlichen Feld. In allen neun Tests unter verschiedenen Magnetfeldbedingungen im Süßwasser (beide Arten im natürlichen Erdfeld, bei kompensierter Nordkomponente und bei auf geographisch Süd verlagerter Nordkomponente) lag die bevorzugte Richtung zwischen $93^{\circ}$ und $184^{\circ}(\mathrm{SO})$. In vier dieser Fälle stellten sich die Aale auch in entgegengesetzter Richtung ein. Es wird diskutiert, wodurch Unterschiede in der Richtungseinstellung $z$ wischen Feld-und Laborversuchen zustande kommen konnten und wie weit magnetische oder elektrische Reize die Richtungswahl bedingen. Ein ökologisches Beispiel aus dem Gebiet der Elbmündung macht die vermutlich kombinierte Wirkung von Erdmagnetismus und Salzgehalt auf die Aalorientierung offenbar: das in Feldversuchen ermittelte Schwimmen in nördlicher Richtung wird erst beim Eintritt der Aale in Meerwasser geringer Salinität aktiviert.
\end{abstract}

\section{INTRODUCTION}

European eels (Anguilla anguilla) on their spawning migration in the North Sea obviously swim on a compass course which is directed in a northern to northwestern direction (T'Esch 1972, 1974). The mechanism which enables the silver eels to have a constant directional choice is unknown. Silver eels investigated in a circular tank exhibited a similar directional preference, provided the test animals were caught during their migration in the Elbe estuary and transported immediately in sea water tanks to the laboratory on the Island of Helgoland to be examined a few days after capture (TESCH \& LeLeK 1973a). The results of the laboratory investigations rule out that visual stimuli, olfaction, pressure or perception of the stream flow provided cues for the directional constancy. 
Branover et al. (1971), Vasilyev \& Gleiser (1973) and Vasilyev et al. (1973) observed in glass eels and older juvenile stages of $A$. anguilla the ability to respond to changes in the magnetic field. The capability to "perceive" the direction of magnetic fields was reduced if strong artificial magnetic fields were induced. Other investigations demonstrated that eels can perceive very weak electric fields. It was supposed that magneto-hydrodynamical effects which produce electrical fields could be involved (McCleave et al. 1971, Rommel \& McCleave 1973).

Using the method of photographing the directional choice of silver eels in a circular tank (TESCH \& LELEK 1973b), it is also possible to examine the directional behaviour under conditions of a changed geomagnetic field. The results presented here were obtained by this technique and include the use of Helmholtz coils for the generation of artificial magnetic fields. In this study, in addition to silver eels of $A$. anguilla from two different locations, individuals of $A$. rostrata caught during their spawning migration on the North American east coast were compared by exposures to a modified geomagnetic field.

\section{MATERIAL AND METHODS}

Migratory European eels in the so-called silvery stage (body length $30-40 \mathrm{~cm}$ ) were selected from commercial catches in two locations of the River Elbe in Western Germany. Nine males were from fyke-net catches in Hamburg harbour on August 26 and 27, 1973. Examination of these eels took place from August 28 to September 5, 1973. Eleven males were caught at the end of October in the Elbe estuary in the same location [Brunsbüttel as described by Tesch \& LeLeK (1973b) by a cutter with a framed gape net (a stow net)]. They were examined from November 6 to 11, 1973. Five female American eels ( $A$. rostrata) in the silver stage and about $70 \mathrm{~cm}$ long were caught by commercial fishermen near Kingston, Rhode Island (USA). They were flown to Hamburg at the end of October 1973 immediately after capture, and were examined on October 30 and from November 19 to 29, 1973.

The eels were maintained in fresh water at $12^{\circ}$ to $14^{\circ} \mathrm{C}$. One set of experiments was conducted in fresh water (tap water); another set was performed in sea water transported to Hamburg from the Helgoland area. The salinity was $>30 \%$.

The plastic circular tank $(1 \mathrm{~m}$ diameter, $50 \mathrm{~cm}$ height, water level $35-40 \mathrm{~cm}$ with a bottom of transparent plexiglas) and the recording camera, as well as all other experimental installation and procedure, were the same as described earlier (TESCH \& LELEK 1973b). Instead of a metal stand and a plastic cover, a fibreglass reinforced stand made of polyester tube was installed underneath the circular tank to eliminate interference with the magnetic field (Fig. 1). During observation periods the eels were kept in total darkness except when illuminated by photographic flash every 10 to $30 \mathrm{~min}$ utes to photographically record their orientation.

The circular tank was framed by two square, wooden Helmholtz coils (Fig. 2), the distance between which was $1.06 \mathrm{~m}$. Coils each had 25 turns of $4.5 \mathrm{~mm}$ copper wire and were connected in series. The current was taken from the mains supply through a constant current rectifier and could be adjusted from 0 to 8 amps. An ammeter indicatad the current. 


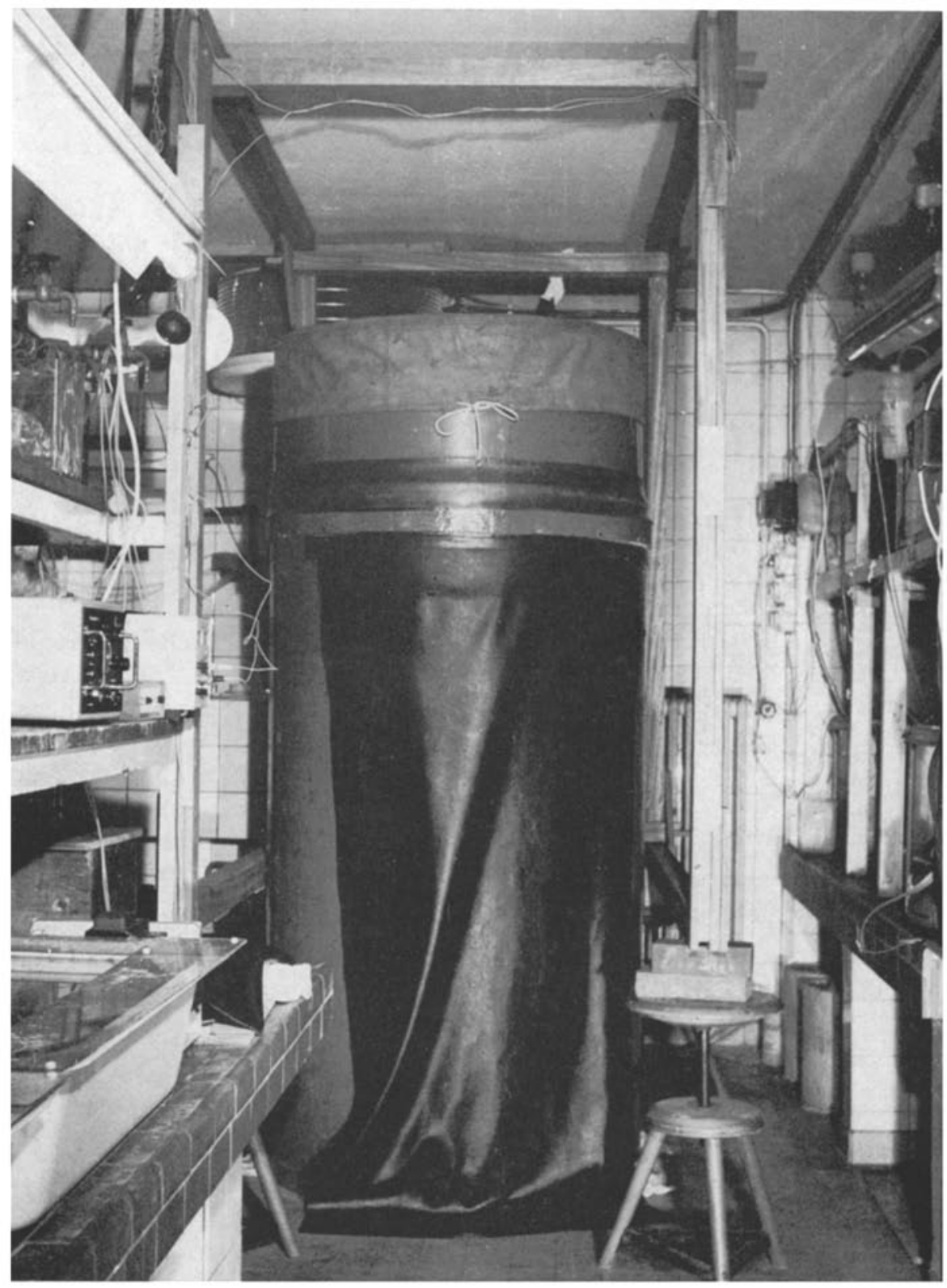

Fig. 1: Experimental arrangement of recording the directional choice. In the centre is the fibreglass reinforced polyester stand with the circular tank on top of it, on the left and right sides parts of the Helmholtz coils, on the left margin outside of the coils is a constant current source and timing apparatus for the camera 


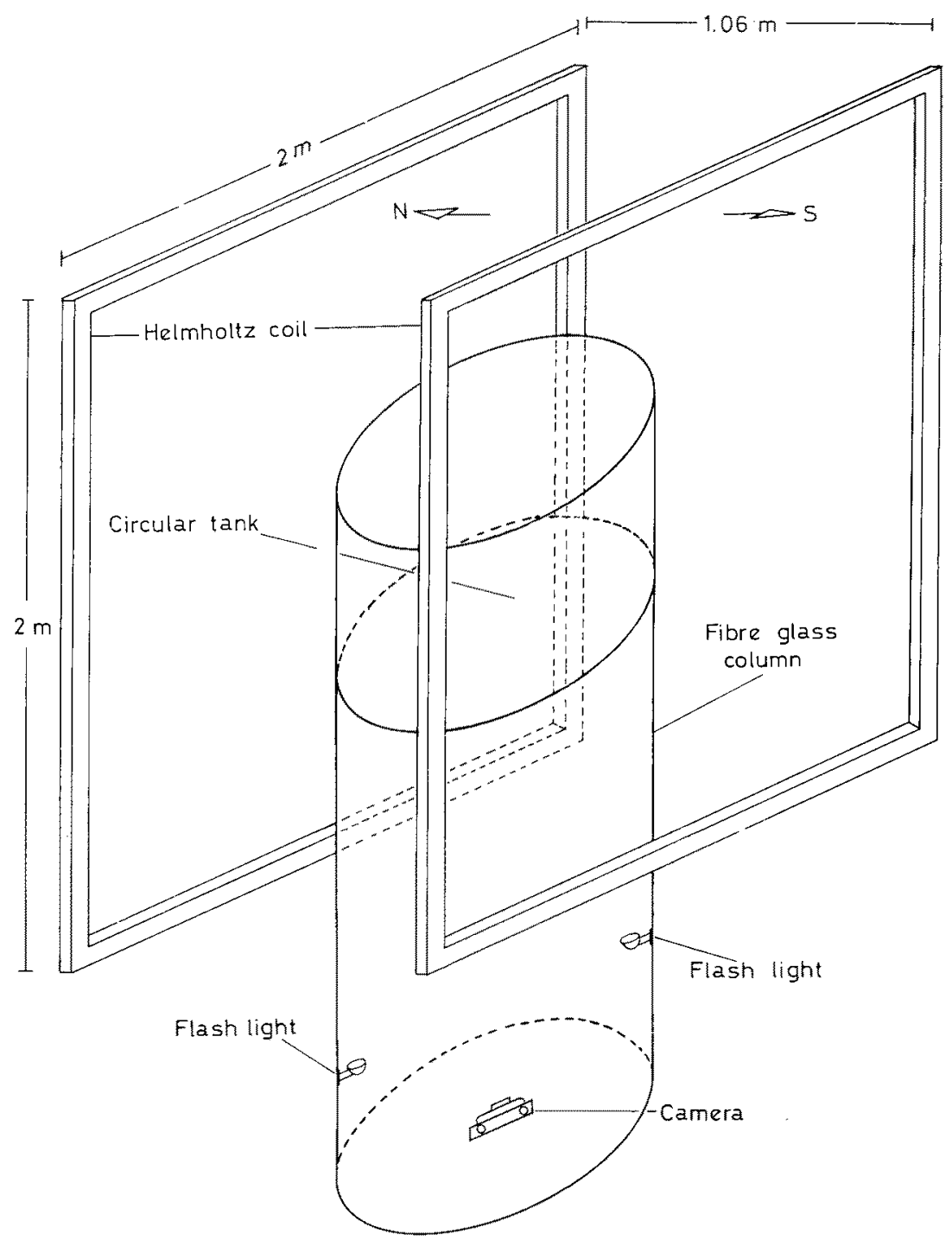

Fig. 2: Coil arrangement around the circular tank and dimensions

The total intensity of the geomagnetic field $(F)$ in Hamburg is about 0.48 Gauss, the horizontal intensity (H) 0.18 Gauss and the inclination (I) $68^{\circ}$. In the circular tank in the basement laboratory of the Biologische Anstalt Helgoland in Hamburg, the north component of the horizontal field $(X)$ measured by means of a Foerster Sonde was 0.18 Gauss. The east component $(Y)$ amounted to $<-0.01$ Gauss. Compensation of $\mathrm{X}$ by current flow through the Helmholtz coils to a value of about zero was effected by a current of $0.8 \mathrm{~A}$; reversal of $\mathrm{X}$ (geographic North to South) was attained at 
1.7 A. If, at compensation of $\mathrm{X}$ to zero in the centre of the bottom of the circular tank, a value of 0.000 Gauss was measured, at some peripheral points of the tank $X$ amounted to a value not higher than 0.005 Gauss.

Examination of the directional position of the eels took place with $\mathrm{X}$ compensated to zero, with $\mathrm{X}$ reversed from North to South, and with normal $\mathrm{X}$ relationships in the BAH laboratory as a control. Each test lasted 17 to 22 hours (in two cases 4.5 or 12 hours) including the night period. As in earlier experiments (TESCH \& LeLEK 1973b) day and night results were compared and no difference was found.

The mean angle (direction), the concentration, and the angular deviation were calculated. The statistical treatment of the results was performed as proposed by BATSCHELET (1965): a $\chi^{2}$ test to determine if a non-uniform circular distribution was present (see also TESCH \& LELEK $1973 \mathrm{a}$, b); the Rayleigh test for testing significance of preferred direction; a non-parametric two sample test (also a $\chi^{2}$ test) for differences in angular deviation between samples. A difficulty arose since many of the circular distributions resulted in a bimodal distribution, as found earlier (TESCH \& LELEK 1973a). For this reason, in all cases in which a bimodal distribution was found, the calculation of the mean angle was performed by the method of "doubling the angle" (BATscheler 1965). A bimodal calculation was conducted in each sample which exhibited no significance by unimodal treatment through the Rayleigh test. Smoothing of the circular distribution rendered no better test results, but smoothed graphical illustration (Fig. 4 and 5) presents the differences more clearly. The procedure for smoothing the single directional frequences $(\mathrm{fm})$ was a follows: $\mathrm{fm}=\mathrm{fm}-1+2 \mathrm{fm}+\mathrm{fm}+1 / 4$.

There is a possibility that, in these investigations, the single specimens tested together could affect each other and bias the result (BATSCHELET, personal communication). In a later experiment (TESCH unpublished) an examination of each single specimen was performed. A comparison of specimens tested singly and together showed no difference in their directional choice.

\section{RESULTS}

A summary of the circular distributions exhibited by the different experiments is given in Table 1. Table 2 presents the mean angles and their level of significance, and Table 3 the mathematical-statistical treatment of the differences. The preferred directions of all silver eels kept in either sea water or in fresh water deviated to the right (increase of the azimuth angle between $5^{\circ}$ and $110^{\circ}$ ) when the North geomagnetism (X) was compensated to zero (Fig. 3). Figure 4 presents an example of these differences by mean of a circular distribution graph. Reversal of the North magnetism (X) from North to South resulted in no consistent change of the azimuth angle, although in fresh water an increase occurred in all three cases. The most striking findings were the differences between the directional behaviour in sea water and fresh water (Fig. 3). In sea water both the controls and the eels under a reversed magnetic field (X) travelled north- or southward. If the field was compensated to zero they pointed in an easterly direction. In fresh water the preferred direction was to the right, i. e. southeast under all three experimental conditions or, to a lesser degree, in the opposite direction. The general impression is that either compensation of the North magnetism to zero or 


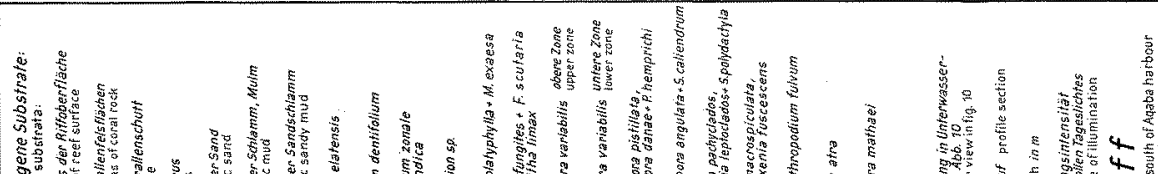

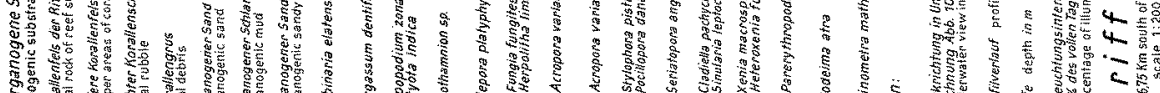
mintwint. -

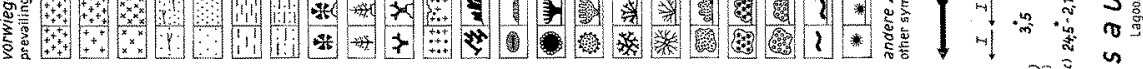
molnon

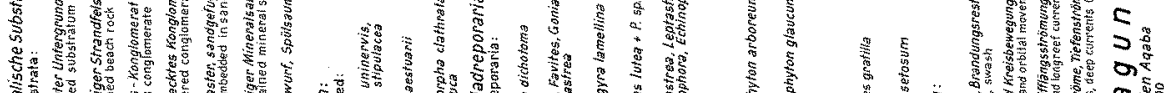

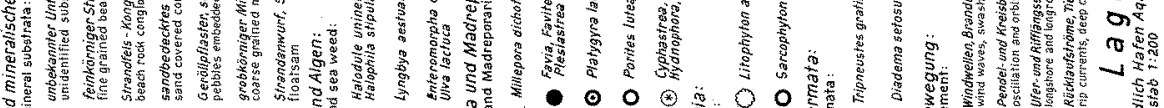

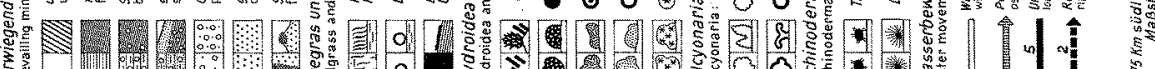

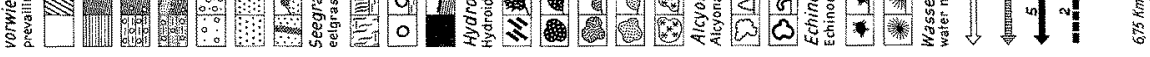

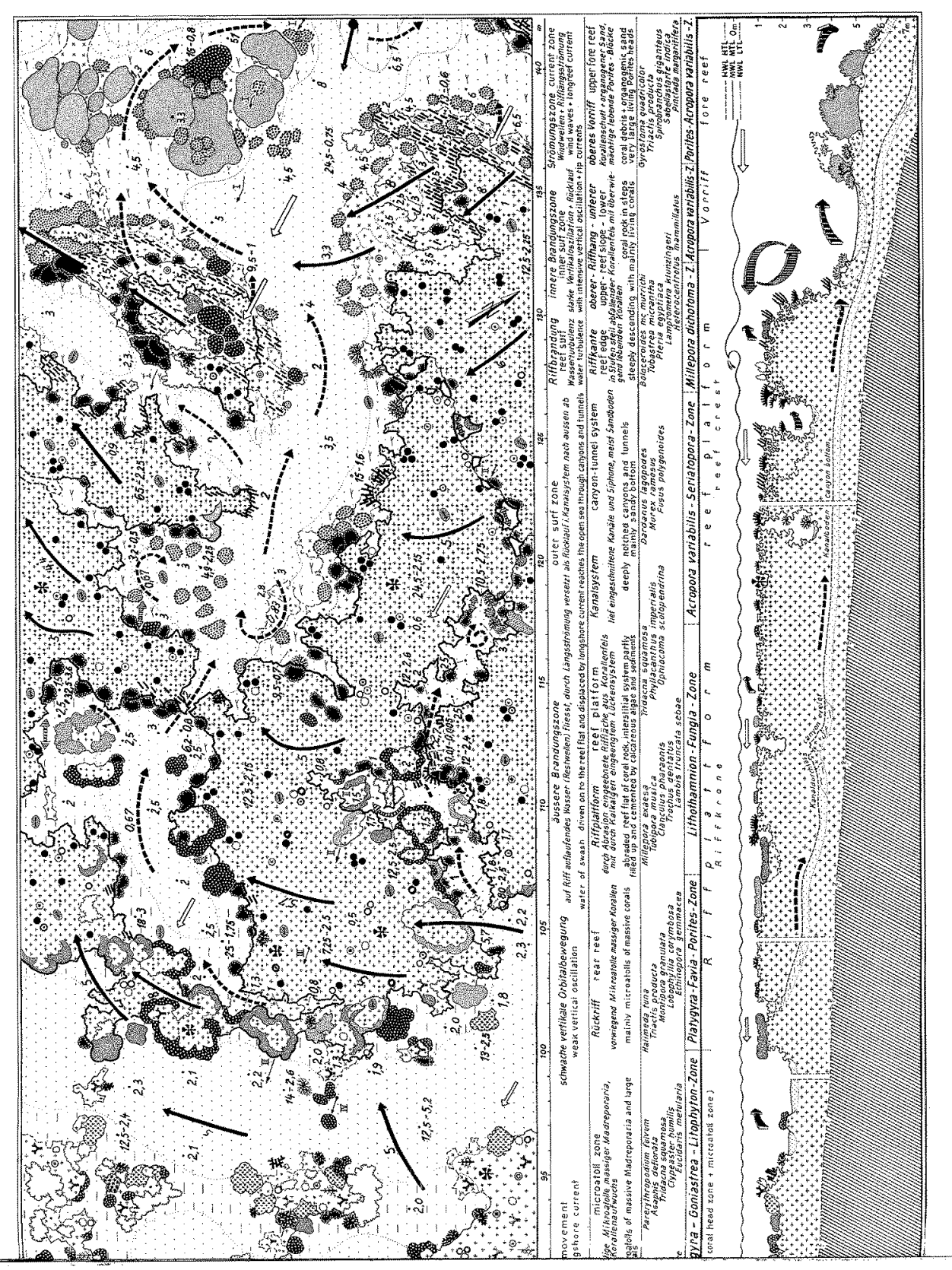


Directional choice of eels

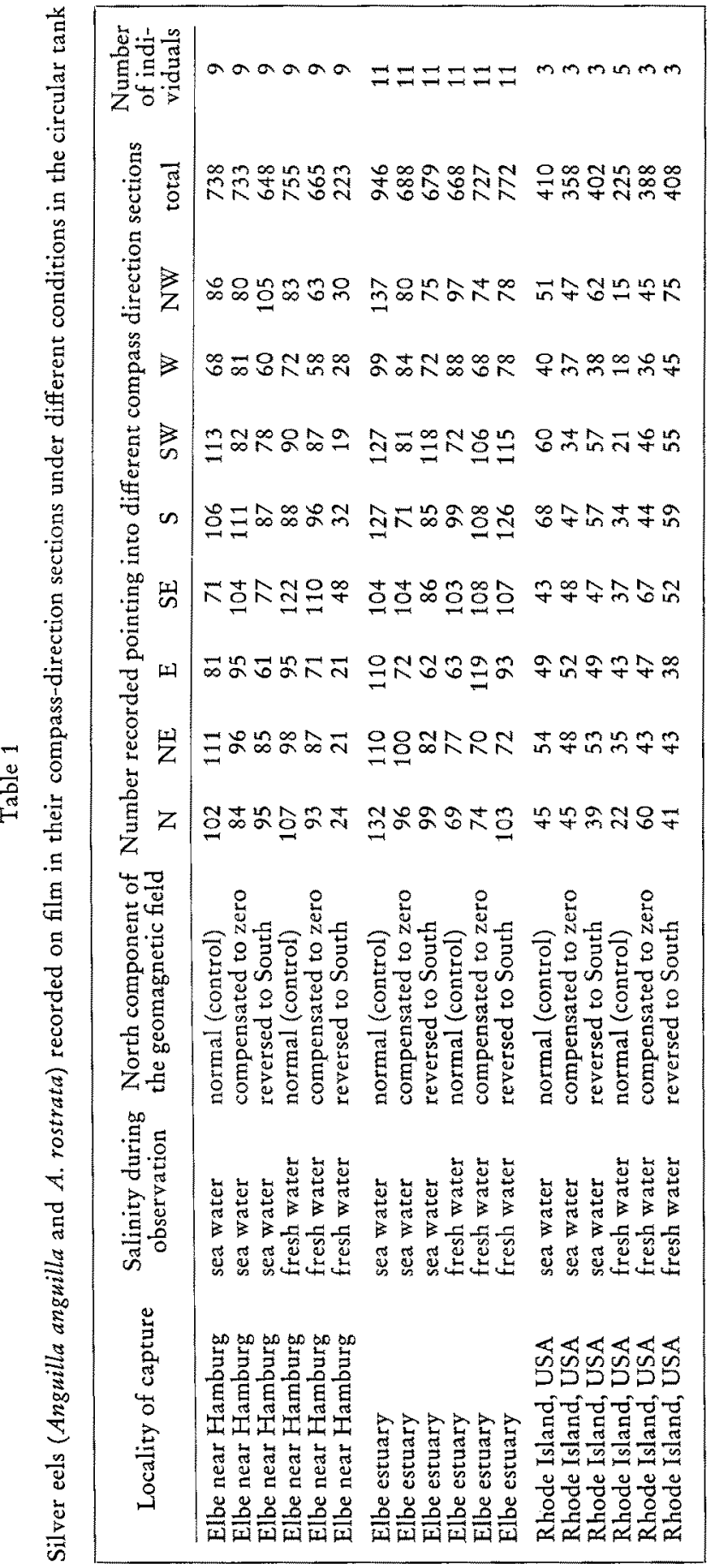




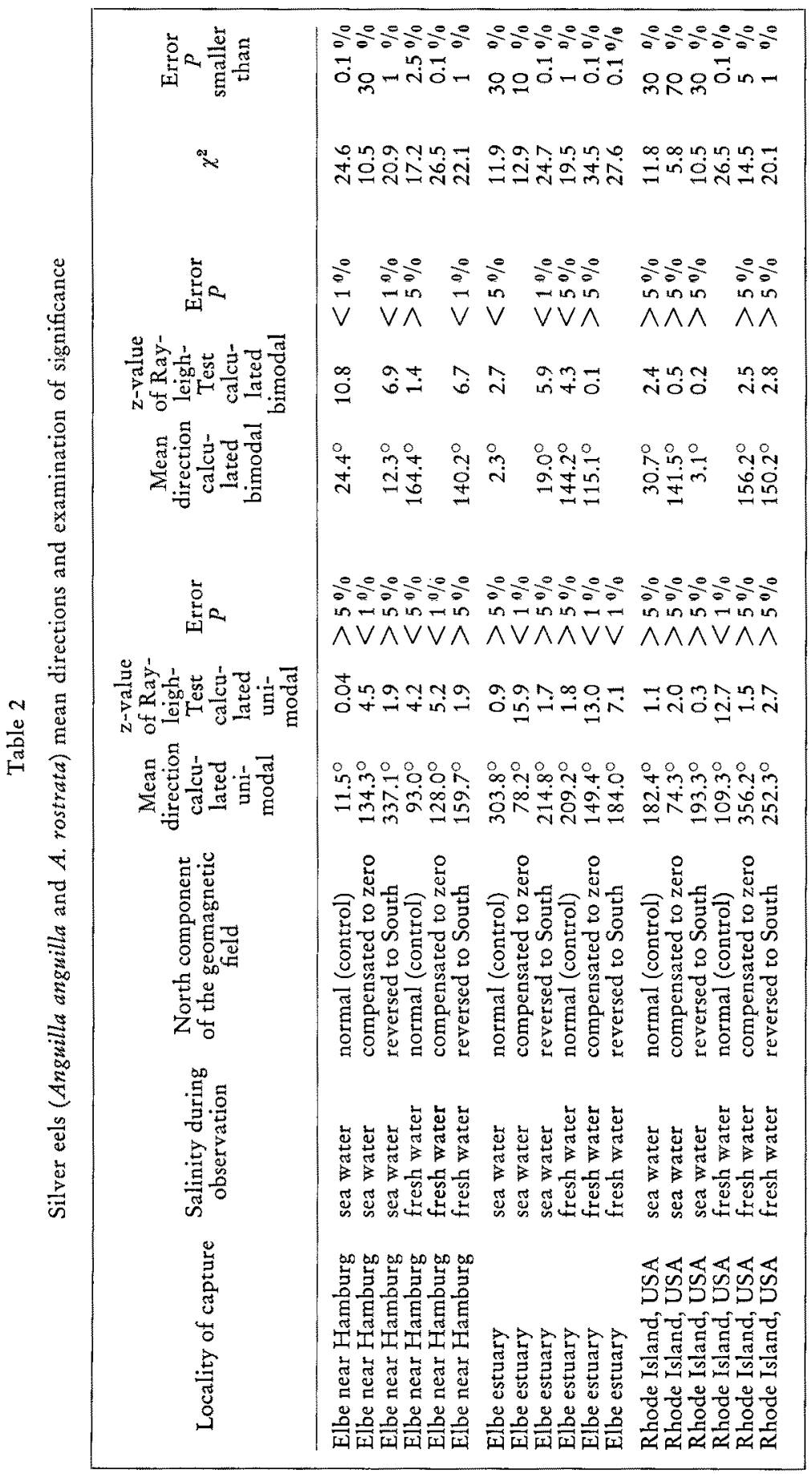




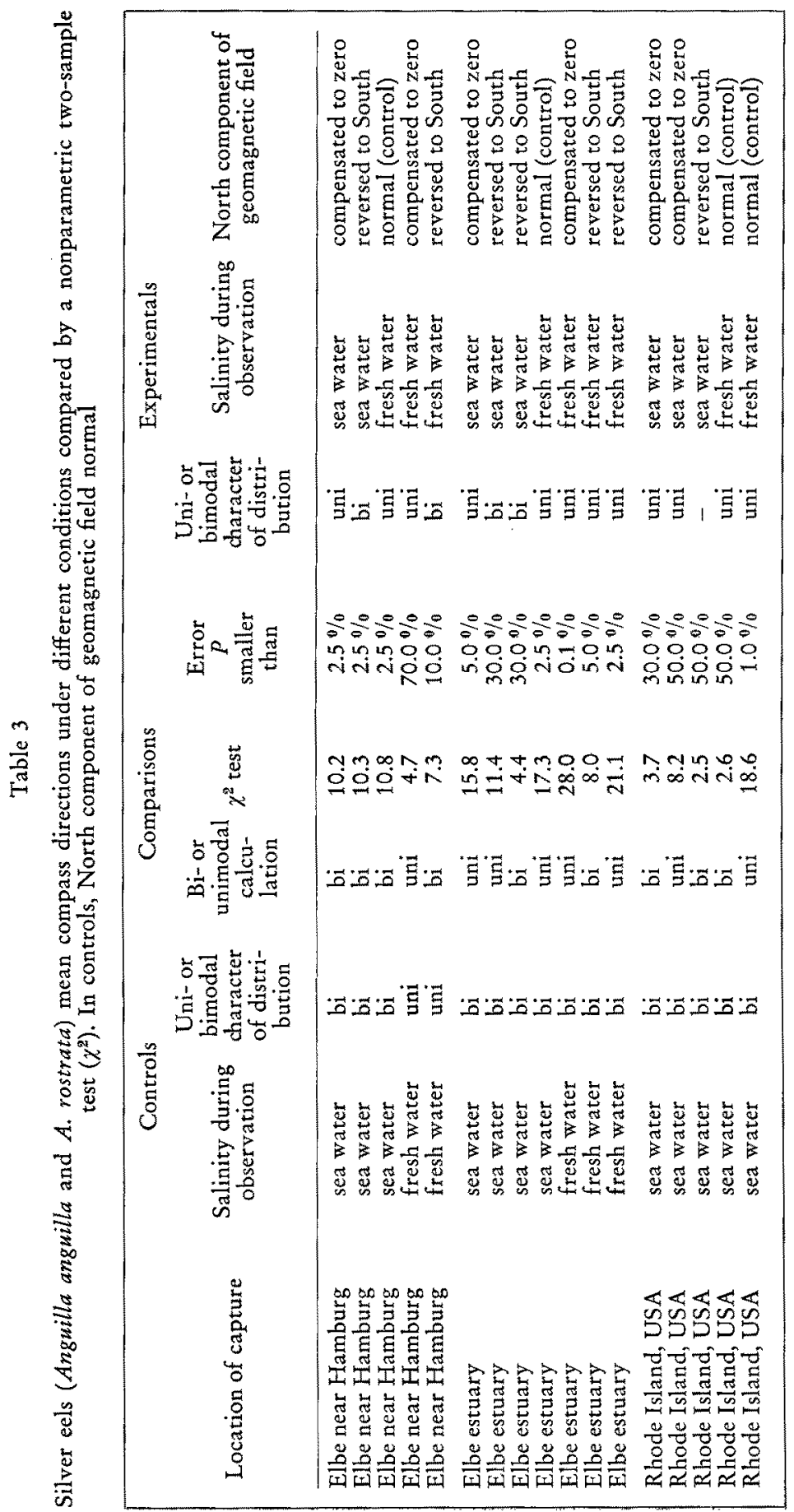


change from sea water to fresh water altered the directional choice from a northern or southern direction to an eastern or, to a lesser degree to a western direction.

The Rayleigh test indicated significance for all results obtained from $A$. anguilla, except the controls of the Elbe estuary, if the highest values are always taken whether from unimodal or bimodal treatment (Table 2). Also the $\chi^{2}$ test (test of fit) exhibited high significance for most values, or in two cases, slightly below the $90 \%$ level. The
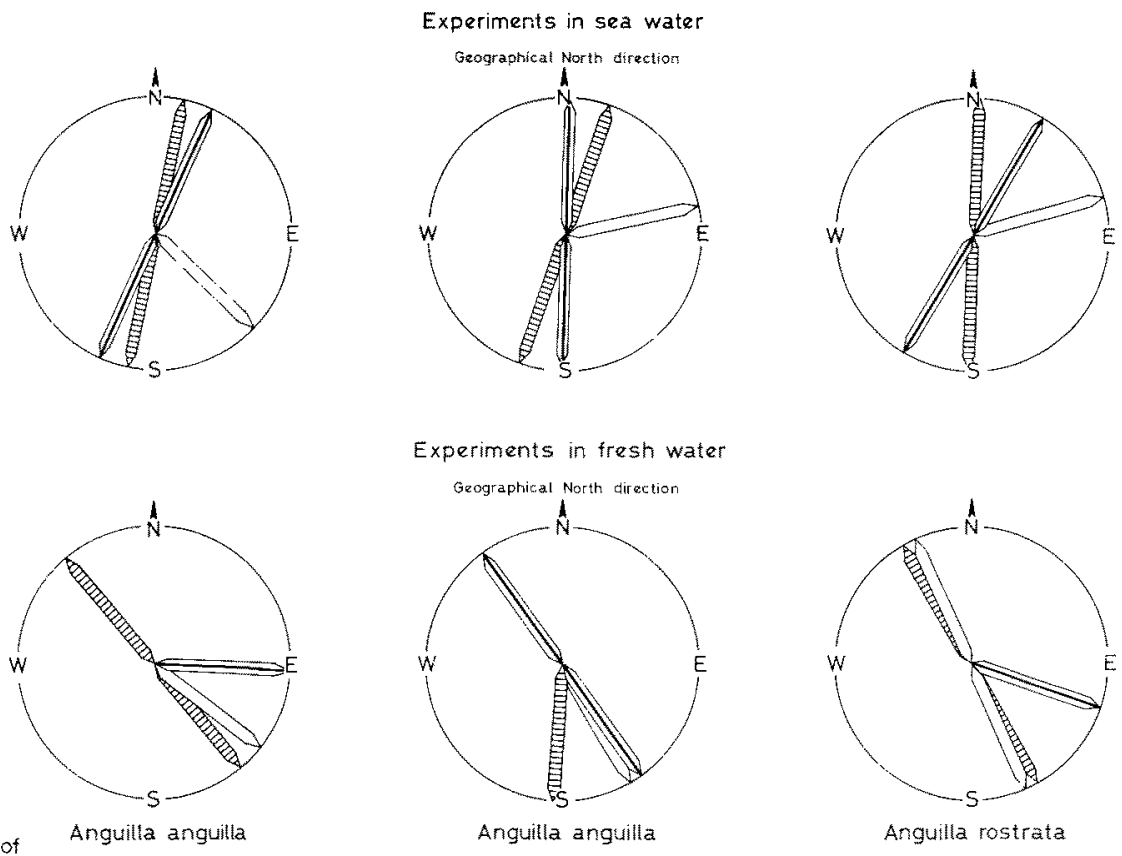

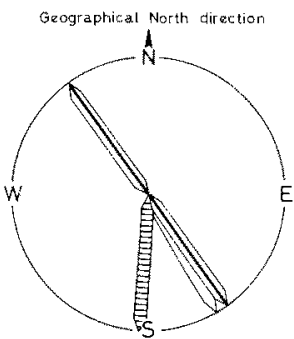

Angutilla anguitia

Elbe estuary

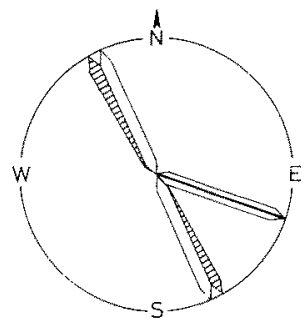

Anguilla rostrata

Rhode Island, USA

sapture: Elbe near Hamburg

$\longleftrightarrow$ Normal geomagnetism Horizontal North geomagnetism
compensatzd to zero

Fig. 3: Mean directional preferences of Anguilla anguilla and Anguilla rostrata examined under different conditions of the geomagnetic field, in sea water and in fresh water and from different locations

Rayleigh test values observed in $A$. rostrata are generally not significant. This is probably due to the small samples and number of observations.

A comparison of the differences between experimental groups on the basis of the $\chi^{2}$ test is presented in Table 3. In $A$. anguilla the striking differences between sea water and fresh water treated animals mentioned is accentuated by significant $\chi^{2}$ values (both samples $2.5 \%$ error). The same is true if the values for eels under compensated conditions and controls are compared $(2.5 \%$ and $5 \%$ error).

Although on the basis of the comparatively small sample size of $A$. rostrata directional concentrations of the circular distributions and their differences are mostly 
uncertain, a representation of the distribution graphically on the basis of a linear distribution seems to deliver clear results (Fig. 5). It becomes evident from the graph that eels in a compensated field exhibit a completely different (i. e. shifted by $90^{\circ}$ )

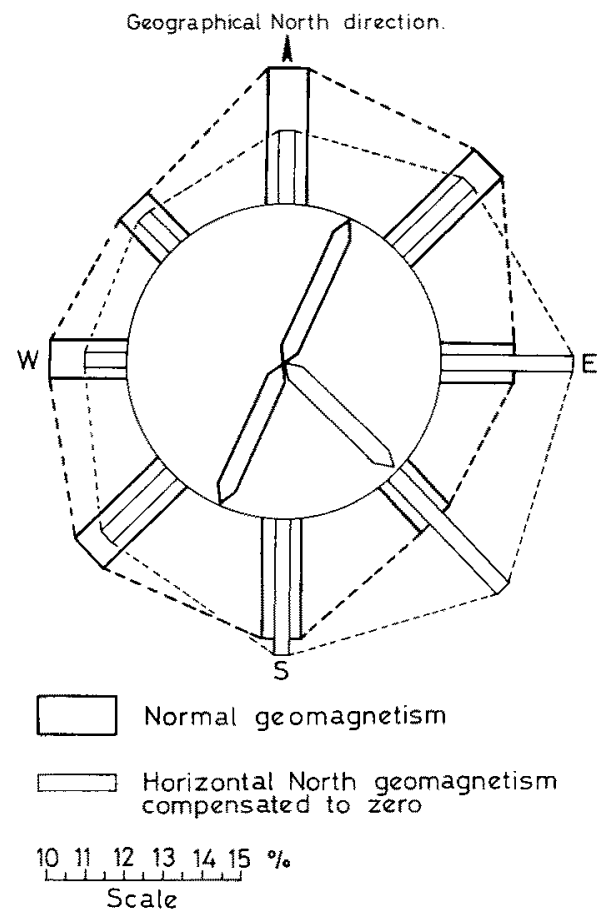

Fig. 4: Directional choice (in percent) of Anguilla anguilla, from the Elbe River at Hamburg examined in sea water, presented by a (smoothed) circular frequency distribution graph., with normal geomagnetic conditions (controls) and with North component of the horizontal geomagnetic field compensated to zero

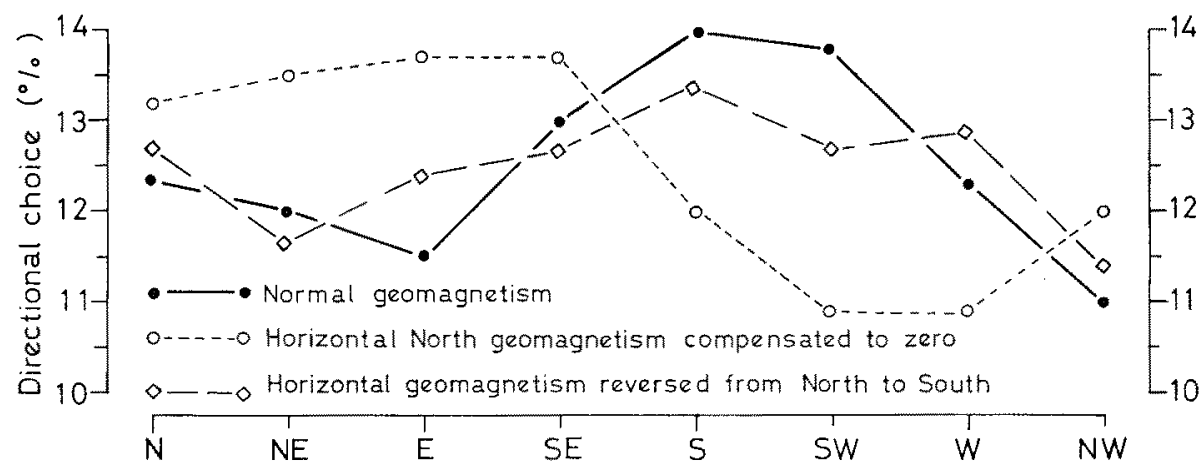

Fig. 5: Directional choice of Anguilla rostrata, examined in sea water, presented by a (smoothed) linear frequency distribution graph, with normal geomagnetic conditions (controls) with the North component compensated to zero, and with the North component reversed to South 
directional behaviour compared with controls. This is in agreement with the results on A. anguilla (Fig. 4).

Although in a small experimental tank like the one used, effects such as generation of electric currents by means of the fish's movement through the geomagnetic field seem to be unlikely, some observations on change of position at intervals of 6 seconds indicated that movement is rare. Every 6 seconds a picture of the eels position was taken; thus nine comparisons of succeeding photos were possible. Out of 77 eel positions $41(53 \%)$ exhibited no positional change; others revealed only slight changes.

\section{DISCUSSION}

These investigations have shown that the directional position of silver eels obviously depends on the geomagnetic field. This is evident from the differences between the directional choice under a compensated horizontal North magnetism (X) and the controls of Anguilla anguilla in sea water, as well as from similar changes of direction in all three samples of Anguilla sp. In fresh water the changes were not as clear as in sea water but the directional choice of $A$. anguilla in fresh water was significantly different from that in sea water. The preferred direction in sea water was northerly and in fresh water easterly to southeasterly (in one case also in the opposite direction). Reversal of the North component of the geomagnetic field (X) to geographic South resulted in no consistent angular changes.

A directional preference of North or South, as in the controls, was also found during earlier investigations (TESCH \& LELEK 1973) in $A$. anguilla examined in 1971 under natural geomagnetic field. This was especially true for yellow (non-migratory) eels as well as for early stages of silver eels. Undisturbed migratory eels in 1971 preferred a northwesterly direction $\left(321^{\circ}\right.$ ) with a high level of significance (Rayleigh test: $z=14.1 ; p<1 \%$. The silver eels from the Elbe estuary in the present investigations were caught in 1973 at nearly the same place but were not as undisturbed as the 1971 specimens: after capture they were transported and maintained in fresh water and they had to endure a longer delay before examination. This may be the reason for the circular distribution being more bimodal than in 1971. In addition, the number of measurements was not as great as 1971. The unimodal calculation of the mean direction results in a northwesterly direction $\left(303^{\circ}\right.$; Rayleigh test: $z=0.9$; no significance) as in 1971.

The question now arises as to why, under the condition of the North geomagnetism (X) compensated to zero, the circular distribution is not uniform. We still always find an orientation to the east. This may be due to the fact that the horizontal magnetic field $(\mathrm{H})$ also exhibits an easterly component $(\mathrm{Y}<-0.01$ Gauss), which after compensation of magnetic North supplies enough stimulation for further directional orientation. This would imply a very high sensitivity. Only compensation of $\mathrm{Y}$ to zero or reversal to the West can resolve this problem.

European robins (Erithacus rubecula) have been shown to be disoriented if placed in rooms of a total intensity (F) less than 0.30 Gauss, but adaptation to a weakened geomagnetic field was possible (WILTSCHKo 1968). It was also found, that not only the 
horizontal component of the earth's field (X) but also the vertical component (V) was necessary for a directional orientation. Without $\mathrm{V}$ the robins had a bimodal directional choice. They appear to measure the inclination $(J)$ of the geomagnetic field lines (Wiltschko 1972, Wiltschкo \& Wiltschko 1972). In eels a bimodal circular distribution was found only if $F$ was normal and it became unimodal if the horizontal field $(\mathrm{H})$ was weakened by reduction of $\mathrm{X}$. An answer to the question of whether $\mathrm{V}$ is important for the orientation of eels can only be given, if results of experimental reduction of $V$ are at hand. From the results presented it seems likely that for eels the mechanism of utilizing magnetic fields is different from that in birds.

A directional preference along the magnetical meridian and in some cases in an East-West or West-East direction was also observed during periods of rest in goldfishes (Carassius carassius auratus) maintained in circular glass bowls (BECKER 1974). If the total geomagnetic field was compensated by a Helmholtz coil the fishes no longer exhibited a special directional preference. A directional choice dependent on geomagnetism was also found in juvenile eels ( $A$. anguilla) by a quite different technique: the labyrinth method (Branover et al.1971, VASIL Yev et al. 1973). These as well as our own results imply that direct stimulation by magnetism is involved: the labyrinth examination, by the fact that strong magnetic fields rendered the eels incapable of orientation by means of magnetism; in the circular tank investigations, by the fact that only rare movement of the test animals in the tank was exhibited which indicates that hardly any induction and perception of electrical currents by the eels' movements through the earth magnetic field could occur. Electrical currents generated by water movement and their perception, as presumed by McCleave et al. (1971), can definitely be excluded. TESCH (1974) considers such a mechanism of orientation to be too complicated.

Ecologically very important is the influence of salinity on the directional behaviour of the eels, as shown by examination either in pure fresh water or in pure sea water. The degree of salinity is obviously of minor importance. The earlier investigations have shown that brackish water (one part sea water, two parts fresh water) induces a North or South preference of the silver eels (TESCH \& LELEK 1973b). The importance of salinity on the behaviour of juvenile eels under the influence of magnetic fields is also demonstrated by experiments of Vasilyev \& Gleiser (1973). They found that increased salinity also augmented the effectiveness of the magnetical field. The authors attribute these results to the increase in hydrodynamical effects by augmentation of salinity (see discussion above).

The combined dependence of orientation on geomagnetism and salinity can explain many ecological problems in the eels migratory behaviour. One of these is the phenomenon that silver eels iduring their spawning migration approaching the Elbe estuary travel along the north bank of the River Elbe. During their migration in fresh water it is known that they drift in the central parts of the river in the main stream. However, when they contact the brackish water of the River Elbe they are only caught near the North bank, as evidenced by the strong concentration of cutters fishing with framed gape nets each migratory season at this special location. The salinity there is about $2 \%$ (KüHL \& MANN 1953). It is interesting that elvers during their migration from the North Sea into the Elbe are caught in the highest concentrations at this same location 
(Tescr 1971). Probably, with a critical low salinity a change in orientation and behaviour of the elvers at this location occurs. From an ecological point of view, the salinity acts as releaser in the silver eel which produces activity and a swimming in the direction of magnetical lines, i.e. in the Elbe estuary and in the North Sea, northward, as demonstrated by results of telemetric ultrasonic tracking (Tesch 1972, 1974) and conventional tagging and recapture (LüHMANN \& MANN 1958).

\section{SUMMARY}

1. A modified arrangement has been used for the photographic recording of the directional choice of silver eels (Anguilla anguilla and A. rostrata) in a circular tank and under the magnetic action of a Helmholtz coil.

2. The movement of the eels in the experimental tank was very restricted as obvious by photographs taken every 6 seconds.

3. Nine male specimens from the Elbe River near Hamburg, 11 male specimens from the Elbe estuary and 3 to 5 female specimes from Rhode Island (USA) were examined for 17 to 22 hours, either in sea water or in fresh water, and yielded 225 to 946 photographs for each examination.

4. In sea water, eels of all three samples changed their preferred direction from north or south to east, when the normal horizontal north $(\mathrm{X})$ component of the geomagnetic field was compensated to zero. The east component $(Y)$ remained $(<-$ 0.01 Gauss) during all observations. In fresh water, eels also preferred more easterly directions in the compensated field, but to a lesser degree.

5. Reversal of the horizontal North component $(X)$ of the magnetic earth field to the South caused no consistent change in eels examined in sea water compared with the controls. In fresh water a slight but consistent deviation to the right was observed.

6. Sea water and fresh water controls including $A$. rostrata showed a significant directional difference; sea water specimens chose North or South; fresh water specimens selected East to Southeast.

7. Perhaps because of the very small sample of $A$. rostrata, differences in this species and compared with $A$. anguilla were mostly not significant. But in all cases the same tendencies as in the European eels have been observed.

8. The question of whether selection of swimming course is affected by the earth magnetic field itself or by magnetohydrodynamically produced electricity is discussed. Mechanisms of orientation under the influence of geomagnetism seem to be different from those observed in birds.

9. An ecological example from the Elbe estuary is given which demonstrates the combined action of geomagnetism and salinity on migratory orientation of silver eels. It is evident that the salinity necessary to release northward swimming is comparatively low; this was also obvious from the results of earlier laboratory investigations (Tesch \& LeLeK 1973b).

Acknowledgements. The author thanks Mrs. M: BARTEL for technical assistance, Mr. W. DitTrich for designing the Helmholtz coils, Mr. R. EDEL as well as Dr. H. E. Winn, Rhode Island (USA) for providing test animals (A. rostrata), and Mr. J. Marschald for preparing 
the drawings and the photo. I am indebted also to Prof. E. BAtschelet, Zürich, for statistical advice, to Dr. J. D. McCleave, Orono (Maine, USA), Dr. A. B. Stasko, St. Andrews (Canada) and Dr. W. WILtschko for critical reading the manuscript as well as Dr. A. Lelek and Prof. Dr. F. W. Merkel (Frankfurt/M.) for helpful suggestions during the planning stage of the investigations. Part of this work was made possible by a grant of the Deutsche Forschungsgemeinschaft.

\section{LITERATURE CITED}

Batschelet, E., 1965. Statistical methods of the analysis of problems in animal orientation and certain biological rhythms. Am. Inst. biol. Sci, Washington, D.C., 57 pp.

BECKER, G., 1974. Einfluß des Magnetfelds auf das Richtungsverhalten von Goldfischen. Naturwissenschaften $61,220-221$.

Branover, G. G., Vasilyev, A. S., Gleiser, S. I. \& Tsinober, A. B., 1971. A study of the behaviour of eel in artificial and natural magnetic fields and the analysis of their mechanism of reception. (Russ.) Vop. Ikhtiol. 11, 720-727.

KüHL, H. \& MaNN, H., 1953. Beiträge zur Hydrochemie der Unterelbe. Veröff. Inst. Meeresforsch. Bremerh. 2, 236-268.

LÜHMANN, M. \& MANN, H., 1958. Wiederfänge markierter Gelbaale vor der Küste Dänemarks. Arch. FischWiss. 9, 200-202.

McCleave, J. D., Rommer, S. A. \& Cathcart, C. L., 1971. Weak electric and magnetic fields in fish orientation. Ann. N. Y. Acad. Sci. 188, 270-282.

Rommel, S. A. \& McCleave, J. D., 1973. Sensitivity of American eels (Anguilla rostrata) and Atlantic salmon (Salmo salar) to weak electric and magnetic fields. J. Fish. Res. Bd Can. 30, 657-663.

Tesch, F.-W., 1971. Aufenthalt der Glasaale (Anguilla anguilla) an der südlichen Nordseeküste vor dem Eindringen in das Sußßwasser. Vie Milieu (Suppl.) 22, 381-392.

- 1972. Versuche zur telemetrischen Verfolgung der Laidhwanderung von Aalen, Anguilla anguilla, in der Nordsee. Helgoländer wiss. Meeresunters. 23, 165-183.

- 1974. Speed and direction of silver and yellow eels, Anguilla anguilla, released and tracked in the open North Sea. Ber. dt. wiss. Komm. Meeresforsch. 23, 181-197.

- \& LELEK, A., 1973a. Directional behaviour of transplanted stationary and migratory form of the eel, Anguilla anguilla, in a circular tank. Neth. J. Sea Res. 7, 46-52.

- $1973 \mathrm{~b}$. An evaluation of the directional choice in the eel, in captivity. Arch. FischWiss. 24, 237-251.

VASILYEv, A. S. \& Gleiser, S. I., 1973. Changes in activity of Anguilla anguilla L. in magnetic fields. (Russ.) Vop. Ikhtiol. 13, 381-383.

- - Sokovishin, V. A., Sokovishina, L. M. \& Khodorkovsky, V. A., 1973. Magnetoreceptor reactions of hyaloid eel (Russ.). Biofizika 18, 132-137.

WiLtschko, W., 1968. Uber den Einfluß statischer Magnetfelder auf die Zugorientierung der Rotkehlchen (Erithacus rubecula). Z. Tierpsychol. 25, 537-558.

- 1972. Einige Parameter des Magnetkompasses der Rotkehlchen (Erithacus rubecula). Verh. dt. zool. Ges. 65, 281-285.

- \& Wiltschko, R., 1972. Magnetic compass of European robins. Science, N. Y. 176, 62-64.

Author's address: Dr. F.-W. Tesch

Biologische Anstalt Helgoland (Zentrale)

2 Hamburg 50

Palmaille 9

Federal Republic of Germany 